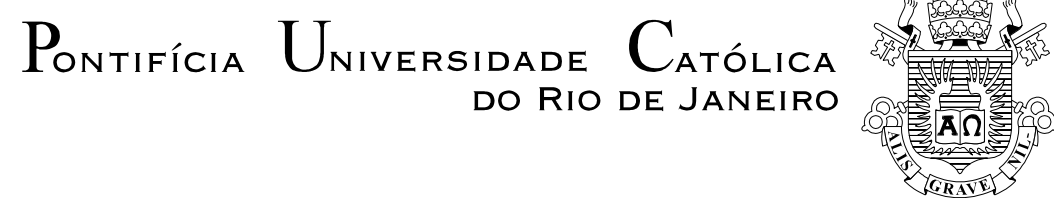

Andréa Araujo de Vasconcellos

\title{
Infraestrutura Verde Aplicada ao Planejamento da Ocupação Urbana na Bacia Ambiental do Córrego D'Antas, Nova Friburgo - RJ
}

\section{Dissertação de Mestrado}

Dissertação apresentada ao Programa de Pós-graduação em Engenharia Urbana e Ambiental do Departamento de Engenharia Civil, PUC-Rio, como exigência parcial para a obtenção do título de Mestre em Engenharia Urbana e Ambiental (opção Profissional).

Orientadora: Profa. Maria Fernanda R. C. Lemos Co-orientador: Prof. Marcelo Motta de Freitas 


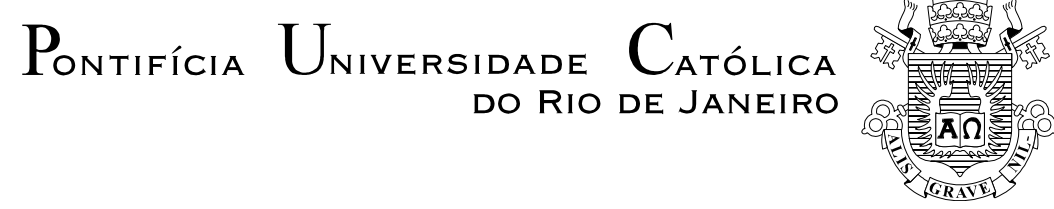

Andréa Araujo de Vasconcellos

\section{Infraestrutura Verde Aplicada ao Planejamento da Ocupação Urbana na Bacia Ambiental do Córrego D’Antas, Nova Friburgo - RJ}

\section{Dissertação de Mestrado}

Dissertação apresentada como requisito parcial para obtenção do grau de Mestre pelo Programa de Pósgraduação em Engenharia Urbana e Ambiental do Departamento de Engenharia Civil do Centro Técnico Científico da PUC-Rio. Aprovado pela Comissão Examinadora abaixo assinada.

Profa. Maria Fernanda R. C. Lemos

Orientadora, Curso de Arquitetura e Urbanismo, PUC-Rio

Prof. Marcelo Motta de Freitas Co-Orientador, Departamento de Geografia, PUC-Rio

Profa. Rachel Coutinho Marques da Silva Programa em Pós-graduação em Urbanismo (PROURB), FAU/UFRJ

Profa. Raquel H. Tardin Coelho Departamento de Urbanismo e Meio Ambiente, FAU/UFRJ Programa em Pós-graduação em Urbanismo (PROURB), FAU/UFRJ

Dra. Lourdes Zunino Rosa Instituto de Pesquisas em Infraestrutura Verde e Ecologia Urbana-INVERDE

Prof. José Eugênio Leal Coordenador Setorial do Centro Técnico - PUC-Rio 
Todos os direitos reservados. É proibida a reprodução total ou parcial do trabalho sem autorização da universidade, da autora e da orientadora.

\section{Andréa Araujo de Vasconcellos}

Graduou-se em Arquitetura e Urbanismo pela Pontifícia Universidade Católica do Rio de Janeiro (PUC-Rio), em 2008.

Ficha Catalográfica

Vasconcellos, Andréa Araujo de

Infraestrutura verde aplicada ao planejamento da ocupação urbana na Bacia ambiental do Córrego D"Antas, Nova Friburgo - RJ / Andréa Araujo de Vasconcellos ; orientadora: Maria Fernanda R. C. Lemos ; co-orientador: Marcelo Motta de Freitas. 2011.

189 f. : il. (color.) ; $30 \mathrm{~cm}$

Dissertação (mestrado)-Pontifícia Universidade Católica do Rio de Janeiro, Departamento de Engenharia Civil, 2011.

Pós-graduação em Engenharia Urbana e Ambiental

\section{Inclui bibliografia}

1. Engenharia civil - Teses. 2. Infraestrutura verde. 2. Planejamento urbano e ambiental. 3. Planejamento urbano sustentável. 4. Ecologia da paisagem. I. Lemos, Maria Fernanda R. C. II. Freitas, Marcelo Motta de III. Pontifícia Universidade Católica do Rio de Janeiro. Departamento de Engenharia Civil. IV. Título. 
À todos que buscam conviver em harmonia com o meio ambiente e que acreditam na possibilidade da humanidade reparar os danos causados à natureza e que ainda têm esperança de mudança nos padrões insustentáveis do desenvolvimento humano. 


\section{Agradecimentos}

Aos meus pais, Patrícia e Alberto, que me incentivaram, apoiaram e orientaram; por acreditarem no meu potencial e ajudarem a trilhar o meu caminho: muito obrigada.

À minha avó, Anésia, por estar sempre por perto e querer o meu bem.

Ao meu irmão, Marcelo, pelo carinho, paciência e colaboração.

À Bella, pela atenção e carinho, por ter se colocado a disposição a me ajudar no que fosse preciso e por ter sido, sim, de grande ajuda.

Aos meus amigos, que foram compreensivos nas minhas ausências e que me apoiaram nos momentos difíceis.

Aos familiares que não citei especificamente, mas o simples fato de torcerem por mim foi muito importante.

Ao grupo de pesquisa do Departamento de Geografia da PUC-Rio, Morfotektos, pela colaboração, ensinamentos, possibilidades de troca de conhecimentos e companhia na ida a campo em Nova Friburgo, em especial a: Hanna, Júlia, Bruno, Murilo e Rodrigo.

À equipe da empresa Ecobrand, por colaborar com informações e dados fundamentais à elaboração desta dissertação, além de muitas vezes ter disponibilizado espaço para o desenvolvimento do trabalho.

Ao meu co-orientador, Marcelo Motta, pelos ensinamentos transmitidos, pela atenção, carinho e oportunidades de aprendizado.

À minha orientadora, Maria Fernanda, por, além de me orientar, me passar confiança e acreditar no meu potencial.

Ao professor Pierre-André Martin, pelas orientações acadêmicas de grande ajuda.

À Renata, por compartilhar e compreender os momentos de dificuldade.

E por fim, um agradecimento especial ao Rodrigo Paixão, por ter me ensinado tudo o que sei sobre o programa ArcGIS, fundamental ao desenvolvimento do trabalho, e por ter sido um verdadeiro amigo, sempre presente e disposto a ajudar. Por isso e por tudo mais, muito obrigada. 


\section{Resumo}

Vasconcellos, Andréa Araujo; Lemos, Maria Fernanda R. Campos (orientadora); Freitas, Marcelo Motta (co-orientador). Infraestrutura Verde Aplicada ao Planejamento da Ocupação Urbana na Bacia Ambiental do Córrego D’Antas, Nova Friburgo - RJ. Rio de Janeiro, 2011. 189 p. Dissertação de Mestrado Departamento de Engenharia Civil, Pontifícia Universidade Católica do Rio de Janeiro.

A dissertação tem por objetivo utilizar os conceitos da infraestrutura verde tida como o estado da arte do planejamento ecológico da paisagem - como instrumento ao planejamento urbano sustentável. A teoria da infraestrutura verde defende o argumento de que a conservação, restauração e manutenção do funcionamento dos sistemas naturais não apenas protegem os valores e as funções ecológicas, mas também promovem diversos benefícios econômicos, sociais e culturais. Primeiramente, analisa a evolução do pensamento ambiental e a forma como ele foi sendo incorporado ao planejamento da paisagem, até chegar à infraestrutura verde. Em seguida, aborda o tema da infraestrutura verde, expondo seus princípios, funções, benefícios e aplicações. Por fim, aplica seus conceitos e métodos na elaboração de um Plano Básico de Ocupação para uma área específica do município de Nova Friburgo (RJ): a Bacia Ambiental do Córrego D'Antas, cuja escolha teve por motivação as trágicas consequências decorrentes das intensas chuvas de janeiro de 2011 na Região Serrana do Estado do Rio de Janeiro, que representaram um exemplo importante de como desastres naturais tomam proporções maiores devido à falta de planejamento e aos erros das ocupações humanas, muitas vezes situadas em áreas indevidas e suscetíveis a riscos. A aplicação do estudo de caso na Bacia Ambiental do Córrego D'Antas tem por objetivo demonstrar a importância da compreensão dos processos ecológicos da paisagem para o planejamento das ocupações humanas. Parte-se do princípio de que entendendo-se o funcionamento dos sistemas naturais, consegue-se direcionar a ocupação com muito mais segurança. O planejamento da rede de infraestrutura verde para a Bacia Ambiental do Córrego D’Antas se dá a partir do mapeamento do suporte biofísico natural, com a identificação das áreas importantes ao funcionamento dos processos naturais da paisagem, classificadas como prioritárias à preservação e como elementos fundamentais à rede. Simultaneamente à identificação das áreas que 
deverão integrar a rede de infraestrutura verde, é feito o direcionamento da ocupação urbana, a partir da definição das áreas propícias à ocupação. Assim, a dissertação apresenta uma proposta metodológica de análise da paisagem para o planejamento da ocupação urbana, baseada nos conceitos da infraestrutura verde e alcançando como resultado final um Plano Básico de Ocupação para a Bacia Ambiental do Córrego D'Antas.

\section{Palavras-chave}

Infraestrutura verde; Planejamento urbano e ambiental; Planejamento urbano sustentável; Ecologia da paisagem. 


\title{
Extended Abstract
}

\author{
Vasconcellos, Andréa Araujo; Lemos, Maria Fernanda R. Campos (Advisor); \\ Freitas, Marcelo Motta (Co-advisor). Green Infrastructure Applied to the Urban \\ Occupancy Planning of the Córrego D'Antas Environmental Basin, Nova \\ Friburgo - RJ. Rio de Janeiro, 2011. 189 p. MSc. Dissertation - Departamento de \\ Engenharia Civil, Pontifícia Universidade Católica do Rio de Janeiro.
}

This dissertation examines the concepts of green infrastructure - taken as the state of the art in ecological landscape planning - as instruments for sustainable urban planning. The theory of green infrastructure holds that conservation, restoration and maintenance of the functioning of natural systems not only protect ecological values and functions, they also promote many economic, social and cultural benefits.

Green infrastructure is a new expression, first used in Florida (USA) in 1994 in a report directed to the American government on strategies to preserve the environment, with the intention of reflecting the notion that natural systems are just as or even more important than the components of conventional (gray) infrastructure to the functioning and development of a community. However, although the expression "green infrastructure" is relatively new, its concept is not, because it is based on studies of landscape design and the interactions between man and nature dating back more than 150 years.

In summary, green infrastructure is a response to the new paradigm of sustainable urbanization, based on the promotion of ecological services and natural landscaping in constructed environments, to enable urban development in harmony with environmental and socio-cultural concerns.

Among the possible applications of green infrastructure is the planning of a green infrastructure network in broader scales (municipal, state, regional or even national), based on protection and rehabilitation of natural areas that are interconnected, to promote natural ecological processes. Green infrastructure should be designed so that an area's natural ecological patterns are replicated and appropriate starting and ending points are provided for the connections of the landscape. In short, the green infrastructure network connects ecosystems and landscapes in a system 
composed of hubs and links, which vary in size, function and domain. The hubs are the origin or destination of the animals, people and ecological processes that move through the system, functioning as anchor spaces of the network, while the links interconnect the system, functioning as ecological corridors, which are fundamental for the maintenance of ecological processes.

Planning a green infrastructure network implies defining which areas will integrate the system and what their functions will be in the network. This definition is intrinsically related to the definition of the land use and occupation, since incompatible uses can compromise the network's functioning. Defining the areas that will be included in the network also entails choosing which areas must be protected and hence not occupied. Therefore, planning a green infrastructure network results, among other outcomes, in the definition of land use and is a useful planning too for sustainable urban planning.

The aim of this dissertation is to demonstrate that the planning of a green infrastructure network can be an effective instrument not only for sustainable urban planning, but also can reduce the risks to the population by preventing tragedies from natural disasters, besides favoring enhanced natural landscapes and preservation of the environment.

This dissertation is divided into five chapters, as follows:

The first, the introduction, briefly sets the context of the worsening urban problems and the negative impacts generated by cities, such as the occurrence of increasingly frequent extreme natural events (floods, heat and cold waves, strong hurricanes, blizzards, landslides and droughts) and the destruction of ecosystems and biodiversity, with the consequent loss of ecological benefits, and touches on the urgent need for solutions that seek to conciliate urban development with the environment.

The second chapter, Green infrastructure, summarizes the theoretical framework underpinning the dissertation's theme. It first provides a brief retrospective of the concepts and practices that served as the base for developing the idea of green infrastructure and then presents its definition, principles, functions, benefits and applications, focusing on the green infrastructure construct as an instrument for land occupation planning. 
The main academic work utilized in examining the theme was the book Green Infrastructure - Linking Landscapes and Communities, by Mark A. Benedict and Edward T. McMahon, published in 2006, from where the concepts, principles and applications presented in this paper were drawn. Mark A. Benedict is recognized as the main proponent of green infrastructure in the United States. He founded the Conservation Fund's Green Infrastructure Program and helped develop the Fund's tools and training programs to support planning of development so as to preserve green spaces.

The third chapter, Green infrastructure applied to urban occupation in Nova Friburgo, Rio de Janeiro, brings an application of the concepts and methods of green infrastructure to the formulation of a Basic Occupation Plan for a specific area in the municipality of Nova Friburgo (Rio de Janeiro state): The D'Antas Stream Environmental Basin. This basin covers an area of 5,820 hectares and is under pressure from urban expansion but is still suitable for planned occupation. It is also one of the areas that were hard hit by the tragic landslides and flooding in the mountain region of Rio de Janeiro in January 2011 (the main reason for choosing it as a case study). As such, it serves as an example of how errors of urbanization and lack of proper land use planning aggravate the consequences of natural disasters.

The case study of the D'Antas Stream Environmental Basin aims to demonstrate the importance of understanding the ecological processes of the landscape for planning human activities. A first important step in planning occupation is to identify the areas that should not be occupied, and the basis of this is understanding the landscape as a network of ecological processes that are reflected in the structure of this landscape, defined as type of snapshot of the distribution of matter and energy according to the ecological processes at a determined point in time. The underlying principle is that comprehending the functioning of natural systems permits more secure direction of land occupation.

The definition of the Basic Occupation Plan for the D'Antas Stream Environmental Basin is based on the planning of a green infrastructure network. The methodology indicated which areas are most important to the maintenance of environmental functions and should thus be protected by restricting occupation. This restriction was defined mainly by selecting the biophysical indicator parameters (terrain, hydrology and plant cover), with the objective of characterizing the natural landscape the main conditioner of the Plan. These restrictions are presented and analyzed in maps. 
The factors restricting occupation are divided into two general themes: physical restrictions and biological restrictions. The presence of Permanent Protection Areas was also a parameter restricting occupation, because besides being required by law, these areas are coherent with the preservation of natural systems due to their varied environmental functions. The next step was to define the areas favorable and unfavorable for occupation in light of the restrictions established, resulting in a map of the study area with classification into three categories: areas fully suitable for occupation, areas suitable for low occupation, and areas unsuitable for any occupation. This classification relied on the results of the diagnostic step and provided the bases for defining the green infrastructure network of D'Anta Stream Environmental Basin. These last areas, considered as having priority for protection, restoration or reclamation, must compose the network, even over the long term, exercising the function of hubs or links.

Development of the methodology applied to D'Antas Stream Environmental Basin used as references the publications "Espaços Livres: sistema e projeto territorial", by the architect and urbanist Raquel Tardin (2008), and "Planejamento Ambiental: teoria e prática", by the biologist Rozely Ferreira dos Santos (2004).

The fourth chapter, Green infrastructure types for the local scale, brings suggestions for multifunctional types of green infrastructure that can be applied at the local level, a scale that was not directly addressed in the case study proposal, but that is considered just as important as the planning scale of the green infrastructure network.

The fifth and concluding chapter presents a summary of the main findings and evidence obtained during the work and also contains some recommendations.

To recapitulate, this dissertation presents a methodological proposal for analysis of the landscape for urban occupation planning, based on the concepts of green infrastructure, with the final result being a Basic Occupation Plan for the D'Anta Stream Environmental Basin.

\section{Keywords}

Green infrastructure; Urban and environmental planning; Sustainable urban planning; Landscape ecology. 


\section{Sumário}

1. Introdução 21

2. Infraestrutura Verde 29

2.1. Origem do Conceito 29

2.2. Definição 32

2.3. Funções e Aplicações 33

2.4. Componentes da Rede de Infraestrutura Verde 39

2.5. Como Projetar uma Rede de Infraestrutura Verde 43

2.6. Infraestrutura Verde como Instrumento para o Planejamento do

Uso e Ocupação do Solo

3. Infraestrutura Verde Aplicada ao Planejamento da Ocupação Urbana em Nova Friburgo - RJ $\quad 49$

3.1. Introdução ao Estudo de Caso e a Relevância de sua Escolha 49

3.2. Localização e Histórico da Ocupação de Nova Friburgo até o Evento das

Chuvas de Janeiro de 2011

3.3. Nova Friburgo e as Chuvas de Janeiro 2011: Tragédia x Inadequação da

Ocupação 56

3.4. Definição do Recorte da Área de Estudo: Bacia Ambiental do Córrego D’Antas 61

3.5. Bases para a Proposta 64

3.5.1. Inventário: seleção de parâmetros indicadores e formação do banco de dados 66

3.5.1.1. Suporte biológico 68

3.5.1.1.1. Uso e cobertura do solo 69

3.5.1.2. Suporte físico 75

3.5.1.2.1. Relevo $\quad 75$

$\begin{array}{ll}\text { 3.5.1.2.2. Hidrografia } & 78\end{array}$

3.5.1.3. Elementos construídos

3.5.1.4. Áreas de proteção permanente (APPs) 87

3.5.2. Diagnóstico: análise dos dados coletados 93

3.5.2.1. Suscetibilidade a riscos 94

3.5.2.2. Restrições à ocupação em relação ao suporte biofísico e à suscetibilidade a riscos 96

3.5.2.2.1. Restrições físicas 97

3.5.2.2.2. Restrições biológicas: grau de conservação da cobertura vegetal 111

3.5.2.2.3. Restrições biofísicas: síntese da avaliação 113 
3.5.2.3. Restrições finais à ocupação

3.5.3. Enquadramento da área segundo a legislação urbana

3.6. Proposta: Plano Básico de Ocupação para a Bacia Ambiental do Córrego D’Antas, Nova Friburgo.

4. Tipologias de Infraestrutura Verde para a Escala Local

\section{Conclusão}

Glossário

Referências Bibliográficas

164

Apêndice 1 - Marcos históricos relevantes à consolidação da infraestrutura verde

Anexo A - Sugestão de parâmetros indicadores

178

Anexo B - Parâmetros mais utilizados em planejamentos ambientais

Anexo C - Funções ambientais das Áreas de Preservação Permanente (APP)

Anexo D - Lei Complementar no 24, 2007: Plano Diretor Participativo de Nova Friburgo (art. 11) 


\section{Lista de Figuras}

\section{Capítulo 2}

Figura 1: Componentes da rede de infraestrutura verde

\section{Capítulo 3}

Figura 1: Mapa do Estado do Rio de Janeiro dividido em cidades e regiões ................... 51

Figura 2: Mapa com a divisão dos distritos de Nova Friburgo ......................................... 52

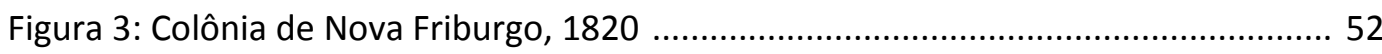

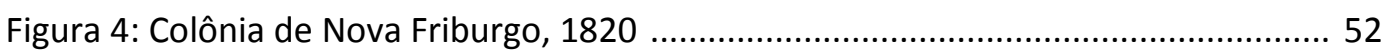

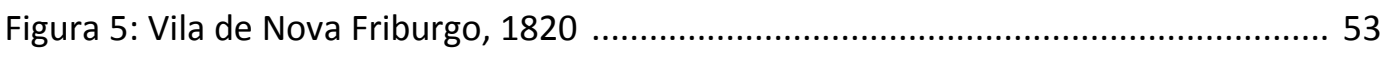

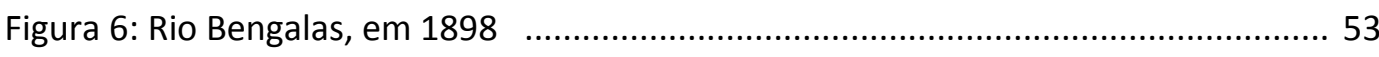

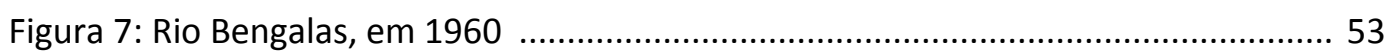

Figura 8: Ocupação das encostas e margens ao longo do rio Bengalas, 2010................. 54

Figura 9: Ocupação das encostas e margens ao longo do rio Bengalas, 2010................. 54

Figura 10: Ocupações em encostas, em Nova Friburgo, afetadas por deslizamentos

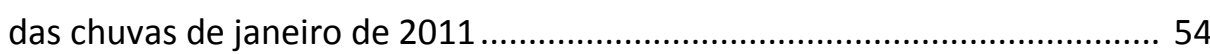

Figura 11: Ocupações em encostas, em Nova Friburgo, afetadas por deslizamentos das chuvas de janeiro de 2011 ................................................................. 54

Figura 12: Rio Bengalas, em 1940, antes da enchente ................................................ 55

Figura 13: Rio Bengalas, em 1940, depois da enchente.............................................. 55

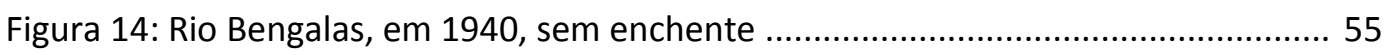

Figura 15: Rio Bengalas, em 1940, com enchente .................................................... 55

Figura 16: Escorregamentos na Região Serrana do Rio de Janeiro em 1967 ................... 57

Figura 17: Bacias Hidrográficas do Município de Nova Friburgo ................................... 62

Figura 18: Limite da área de estudo: Bacia Ambiental do Córrego D’Antas ................... 64

Figura 19: Esquema metodológico de análise das restrições à ocupação ........................ 67

Figura 20: Vista geral do vale principal do Córrego D'Antas ......................................... 77

Figura 21: Duas Pedras vista do bairro Córrego Dantas............................................... 78

Figura 22: Duas Pedras vista do bairro São Geraldo .................................................. 78

Figura 23: Duas Pedras vista do cruzamento das rodovias BR-492 e RJ116 ................... 78

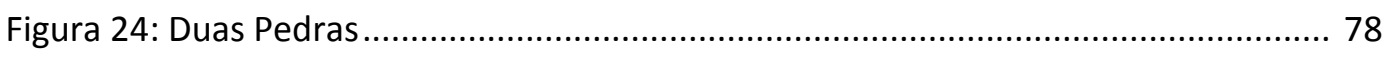

Figura 25: Encontro do Córrego D'Antas com rio Bengalas ........................................... 80

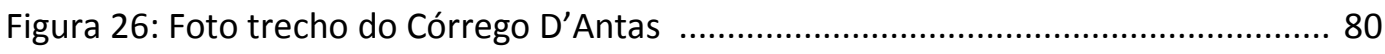

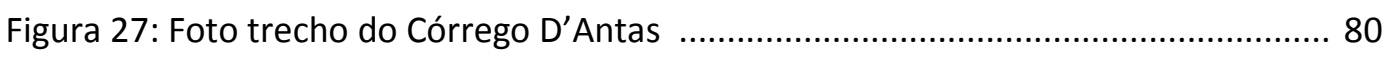

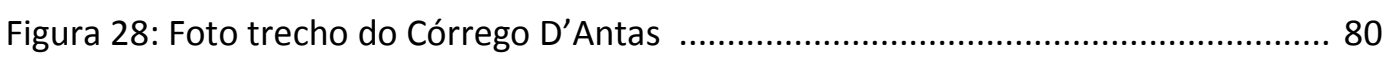

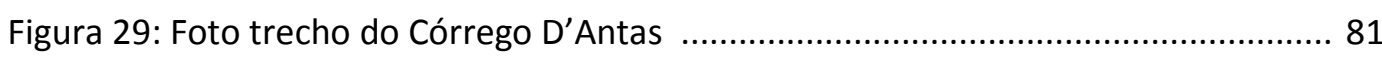

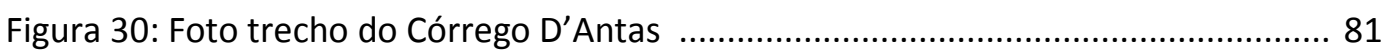

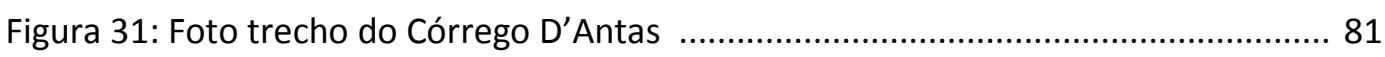

Figura 32: Foto Rio Bengalas. Fonte: Google Earth 07/08/2010.................................... 81

Figura 33: Foto do Rio Bengalas com placa de obra de canalização ................................ 82

Figura 34: Foto do Rio Bengalas com placa de obra de canalização ............................... 82

Figura 35: Entroncamento viário da BR-492 com RJ-116 e RJ-148 ................................ 83

Figura 36: Foto representativa do sistema viário local................................................. 84

Figura 37: Foto representativa do sistema viário local. .................................................. 84 
Figura 38: Foto representativa do sistema viário local................................................. 84

Figura 39: Foto representativa do sistema viário local................................................. 84

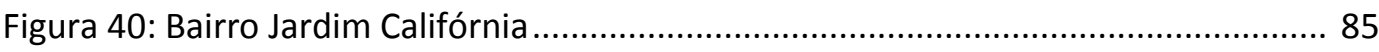

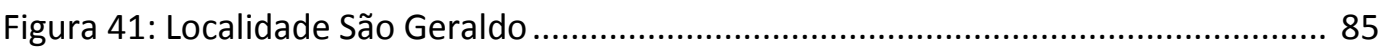

Figura 42: Bairro Córrego D’Antas cortado pela BR-492 …............................................. 85

Figura 43:Propriedade agrícola, próxima a localidade Cardinot .................................. 85

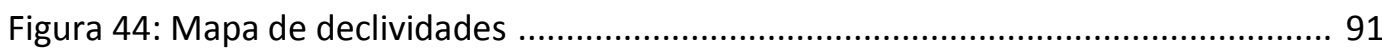

Figura 45: Deslizamentos em encostas com declividade superior a 45 graus ................. 97

Figura 46: Deslizamentos em encostas com declividade superior a 45 graus ................ 97

Figura 47: Localidade Sítio dos Esquilos - deslizamentos atingindo edificações situadas em encostas com declividade superior a 45 graus .......................... 98

Figura 48: Localidade Lazareto - deslizamentos atingindo edificações situadas em encostas com declividade superior a 45 graus 98

Figura 49: Encosta côncava e com declividade superior a 45 graus: bairro Córrego D'Antas antes das chuvas de janeiro de 2011................................. 99

Figura 50: Encosta côncava e com declividade superior a 45 graus: bairro Córrego D'Antas depois das chuvas de janeiro de 2011. 99

Figura 51: Deslizamento em encosta côncava e com declividade superior a 45 graus. ...99 99 Figura 52: Planícies de inundação do Córrego D'Antas afetadas pelas chuvas (2011) ... 100 Figura 53: Planícies de inundação do Córrego D'Antas afetadas pelas chuvas (2011) ... 100 Figura 54: Planícies de inundação do Córrego D'Antas afetadas pelas chuvas (2011) ... 101 Figura 55: Exemplo de ocupações em planícies de inundação ......................................101

Figura 56: Exemplo de ocupações em planícies de inundação ........................................ 101

Figura 57: Topo da montanha Duas Pedra, evidenciando risco natural de deslizamentos de terra e rolamento de rochas 102

Figura 58: Exemplo de ocupação em topo de morro como agravante à susceptibilidade de deslizamento (antes das chuvas de janeiro) .103

Figura 59: Exemplo de ocupação em topo de morro como agravante à susceptibilidade de deslizamento (depois das chuvas de janeiro)

Figura 60: Exemplo de ocupação em topo de morro dentro da área de estudo.............103

Figura 61: Exemplo de ocupação em topo de morro dentro da área de estudo..............103

Figura 62: Foto aérea mostrando ocupações no sopé da encosta atingidas pelos deslizamentos - trecho ao longo do Córrego Dantas e da BR-492 ......104

Figura 63: Exemplo de ocupações em sopés de encostas atingidas por deslizamentos após as chuvas de janeiro de 2011

Figura 64: Exemplo de ocupações em sopés de encostas atingidas por deslizamentos após as chuvas de janeiro de 2011 .104

Figura 65: Exemplo de ocupações em sopés de encostas atingidas por deslizamentos decorrentes das chuvas de janeiro de 2011 105

Figura 66: Exemplo de ocupações em sopés de encostas atingidas por deslizamentos decorrentes das chuvas de janeiro de 2011 ........................ 105

Figura 67: Localidade Sítio dos Esquilos antes da tragédia de janeiro de 2011............ 106

Figura 68: Localidade Sítio dos Esquilos depois da tragédia de janeiro de 2011.......... 106 
Figura 69: Destruição do Sítio dos Esquilos mostra a configuração de um leque de deposição de detritos

Figura 70: Sítio dos Esquilos - exemplo de ocupação em frente de boca de vale ...........107

Figura 71: Sítio dos Esquilos - exemplo de ocupação em frente de boca de vale ........... 107

Figura 72: Mapa de Unidades de Conservação da Natureza instituídas no município de Nova Friburgo

Figura 73: Mapa das Unidades Territoriais de Planejamento de Nova Friburgo ............121

Figura 74: Mapa com as subdivisões das Unidades Territoriais de Planejamento de Nova Friburgo

Figura 75: Localização da área de estudo em relação ao zoneamento da UTP

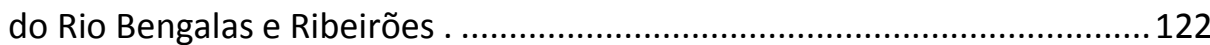

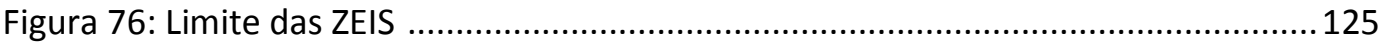

Figura 77: Conflito das ZEIS inseridas na área de estudo $x$ áreas não ocupáveis ..........125

\section{Capítulo 4}

Figura 1: Seção típica de um alagado construído ..................................................... 143

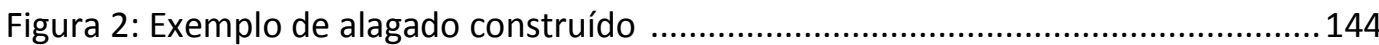

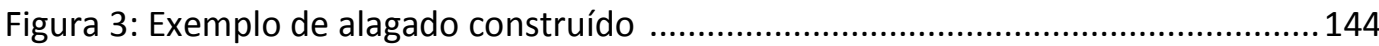

Figura 4: Técnica de bioengenharia para estabilização de margem de rio...................... 145

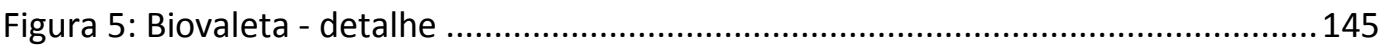

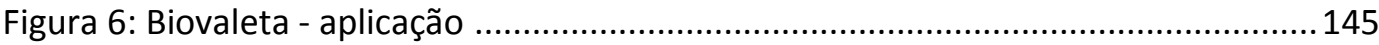

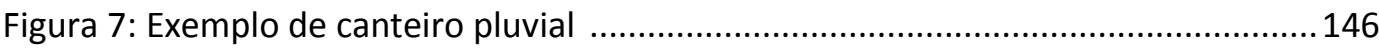

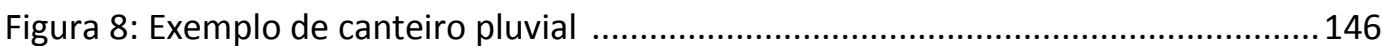

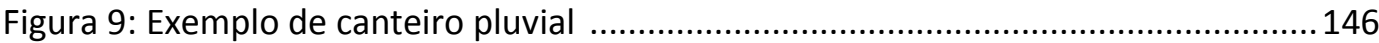

Figura 10: Horta urbana comunitária sob torres de transmissão ................................... 147

Figura 11: Horta urbana sob torres de transmissão (antes) . ...........................................147

Figura 12: Horta urbana sob torres de transmissão (depois) . ...................................... 147

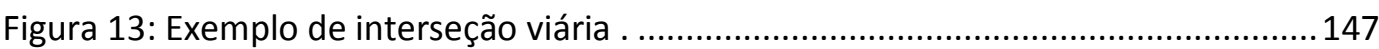

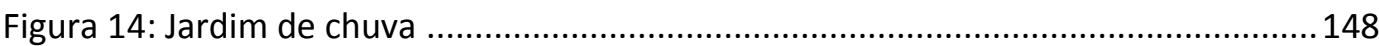

Figura 15: Planta baixa de bacias bioretentoras aplicadas ao longo de via.....................148

Figura 16: Seção AA de bacias bioretentoras aplicadas ao longo de via. .......................148

Figura 17: Seção BB de bacias bioretentoras aplicadas ao longo de via............................ 148

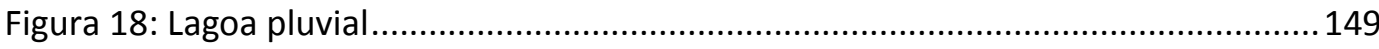

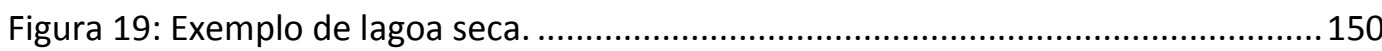

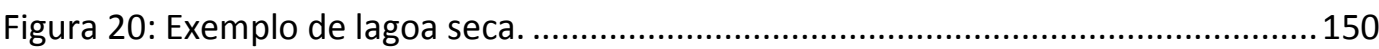

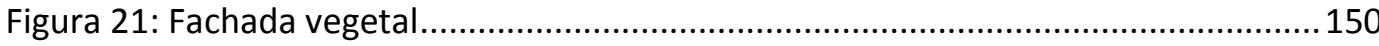

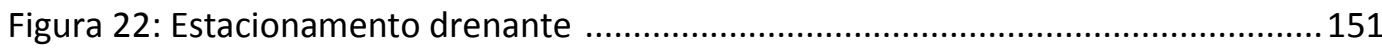

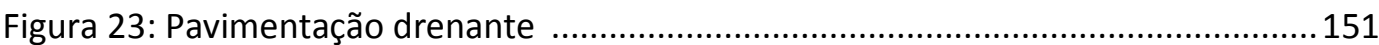

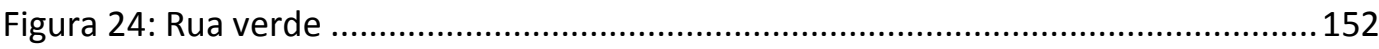

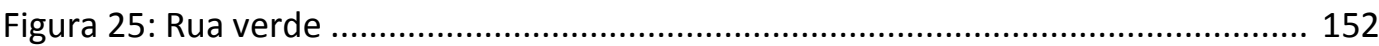

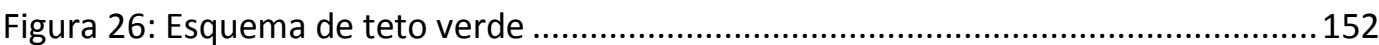

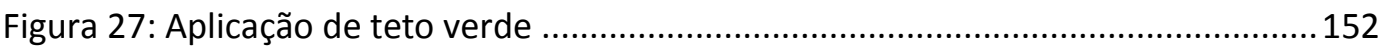




\section{Lista de Tabelas}

\section{Capítulo 2}

Tabela 1: Elementos e funções que podem integrar a infraestrutura verde

\section{Capítulo 3}

Tabela 1: Registros das chuvas nos dias 11 e 12 de janeiro de 2011, pela estação pluviométrica Sítio Sta. Paula .

Tabela 2: Comparativo do quantitativo de unidades a serem removidas em função dos diferentes fatores de restrição à ocupação 


\section{Lista de Mapas (formato A3)}

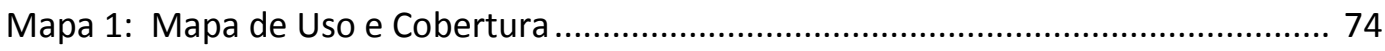

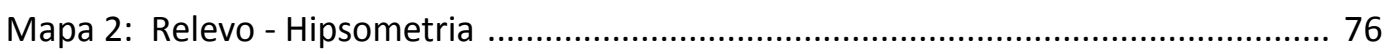

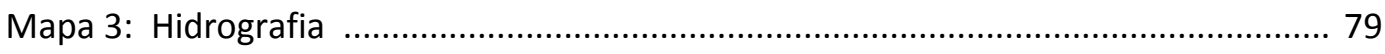

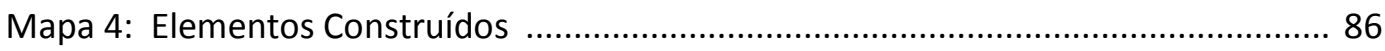

Mapa 5: Áreas de Preservação Permanente (APPs) ……............................................ 92

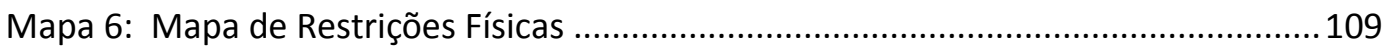

Mapa 7: Mapa de Áreas Não Ocupáveis em Função do Suporte Físico..........................110

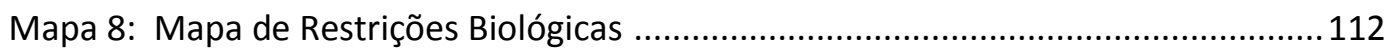

Mapa 9: Mapa de Áreas Não Ocupáveis em Função do Suporte Biológico ...................114

Mapa 10: Mapa de Áreas Não Ocupáveis em Função do Suporte Biofísico ....................115

Mapa 11: Mapa Final de Restrições à Ocupação .......................................................118

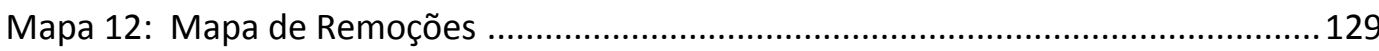

Mapa 13: Rede de Infraestrutura Verde para a Bacia Ambiental do Córrego D’Antas.. 133

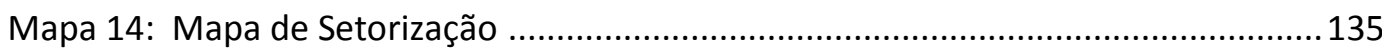




\section{Lista de Siglas}

\begin{tabular}{|c|c|}
\hline AMPLA & Ampla Energia e Serviços S A \\
\hline APA & Área de Proteção Ambiental \\
\hline APP & Área de Preservação Permanente \\
\hline $\mathrm{CF}$ & Constituição Federal \\
\hline CIDE & Centro de Informações e Dados do Estado \\
\hline CONAMA & Conselho Nacional do Meio Ambiente \\
\hline CREA-RJ & $\begin{array}{l}\text { Conselho Regional de Engenharia, Arquitetura e } \\
\text { Agronomia do Rio de Janeiro }\end{array}$ \\
\hline EMBRAPA & Empresa Brasileira de Pesquisa Agropecuária \\
\hline ESRI & $\begin{array}{l}\text { Environmental Systems Research Institute. Empresa } \\
\text { americana especializada na produção de soluções } \\
\text { para a área de informações geográficas, por } \\
\text { exemplo o programa de computador ArcGIS. }\end{array}$ \\
\hline IBGE & Instituto Brasileiro de Geografia e Estatística \\
\hline INEA & Instituto Estadual do Ambiente \\
\hline INMET & Instituto Nacional de Meteorologia \\
\hline MMA & Ministério do Meio Ambiente \\
\hline OMM & Organização Mundial de Meteorologia \\
\hline UCN & Unidade de Conservação da Natureza \\
\hline USDA & United States Department of Agriculture \\
\hline UTP & Unidades Territoriais de Planejamento \\
\hline ZEIS & Zonas de Especial Interesse Social \\
\hline
\end{tabular}


"A proteção da terra é uma expressão de fé no futuro: é um pacto entre gerações."

Charles R. Jordan e Lawrence A. Selzer

(The Conservation Fund) 